\title{
Prevalence of Ferritin, Folate and Vitamin B12 Deficiencies Amongst Children in 5-18 years of Age in Delhi
}

\author{
Umesh Kapil • Neha Sareen
}

Received: 11 March 2013 / Accepted: 16 May 2013 / Published online: 20 June 2013

(C) Dr. K C Chaudhuri Foundation 2013

To the Editor: National Family Health Survey (NFHS-3) documented the prevalence of anemia as $76.4 \%$ amongst children. Studies have documented iron, folate and vitamin $\mathrm{B} 12$ to be the causes of nutritional anemia. However there is limited data on prevalence of iron, folate and vitamin B12 deficiencies amongst children in India. We would like to report results of a sub study undertaken, in a large survey data set, amongst children of 5-18 y in National Capital Territory of Delhi, which has been published earlier.

A total of 1037 children in the age group of 5-18 y were included in the present study. The study was approved by ethical committee of All India Institute of Medical Sciences.

Blood was drawn and transported to the central laboratory at All India Institute of Medical Sciences, New Delhi for separation of serum. Serum ferritin was determined by the enzyme linked immune-sorbent assay (ELISA) method [1]. The levels less than $12 \mathrm{ng} / \mathrm{mL}$ were considered as indicative of iron deficiency. Serum folate was determined by the Radio-immuno assay (RIA) method. The levels less than $3 \mathrm{ng} / \mathrm{mL}$ were considered as indicative of folic acid deficiency [2]. Serum B12 was estimated utilizing the radio isotopic. The levels less than $200 \mathrm{pg} / \mathrm{mL}$ were considered as indicative of cobalamin deficiency [3].

Prevalence of ferritin, folate and B12 deficiencies were observed to be $54.5 \%, 42.0 \%$ and $67.2 \%$ for children in the age group of $5-11 \mathrm{y}$, and $55.0 \%, 30.7 \%$ and $68.3 \%$ for children in the age group of 12-18 y, respectively.

An earlier community based study documented that $88 \%$ of the children below $6 \mathrm{y}$ had low serum ferritin levels [4]. Similarly, the prevalence of folate deficiency as $50 \%$ and cobalamin deficiency as $62 \%$ has been reported earlier [5].

The present study revealed that there was a high prevalence of deficiency of iron, folate and B12 amongst children in the age group of 5-18 y.

\section{References}

1. Forman D, Parker S. The measurement and interpretation of serum ferritin. Ann Clin Lab Sci. 1980;10:345-50.

2. Chanarin I. The Assay and Concentration of Folate in Blood and Other Tissues: The Megaloblastic Anemias. London, Oxford: Blackwell Scientific Publications; 1969. pp. 306-36.

3. Raven JL, Robson MB. Extraction of serum vitamin B12 for radioisotopic and Lactobacillus leichmannii assay. J Clin Pathol. 1975;28:531-9.

4. Kapoor D, Agarwal KN, Sharma S, Kela K, Kaur I. Iron status of children aged 9-36 months in an urban slum ICDS project in Delhi. Indian Pediatr. 2002;39:136-44.

5. Chandra J, Jain V, Narain S, Sharma S, Singh V, Kapoor AK, et al. Folate and cobalamin deficiency in megaloblastic anemia in children. Indian Pediatr. 2002;39:453-7.
U. Kapil $(\bowtie) \cdot$ N. Sareen

Department of Human Nutrition, All India Institute of Medical

Sciences, Ansari Nagar, New Delhi 110 029, India

e-mail: umeshkapil@gmail.com 